\title{
APLNR Gene
}

National Cancer Institute

\section{Source}

National Cancer Institute. APLNR Gene. NCI Thesaurus. Code C138154.

This gene plays a role in peptide hormone-dependent G protein-coupled receptor signaling. 